\title{
Production of Transgenic Rice (indica cv. MR219) Overexpressing Abp57 Gene through Agrobacterium-Mediated Transformation
}

(Pengeluaran Padi Transgenik (indica cv. MR219) Lebih Ekspres Gen Abp57

melalui Transformasi Berperantakan Agrobacterium)

\author{
LaY-Wen TAN, Zuraida A. RAHMAN, HoE-Han GoH, DUK-Ju HWANG, \\ ISMANIZAN ISMAIL \& ZAMRI ZAINAL*
}

\begin{abstract}
Agrobacterium-mediated transformation of indica rice is undoubtedly a challenging task due to the rice recalcitrant nature to transformation process. Therefore, optimization of the transformation protocol is important for specific indica rice cultivar to ensure effectiveness of the transformation. In this study, crucial parameters affecting Agrobacteriummediated transformation were optimized to obtain transgenic rice of local rice cultivar (indica MR219). Embryogenic calli were chosen for inoculation with Agrobacterium tumefaciens strain LBA4404 harbouring a binary vector pH2GW7ABP57 containing gene of interest, Auxin binding protein 57 (Abp57). The parameters that have been optimized were the immersion time, co-cultivation period, acetosyringone concentration and co-cultivation temperature. A total of four days co-cultivation period and 30 min immersion of embryogenic callus are optimum for the transformation of MR 219 with transformation efficiency of $26.4 \%$ and $16.0 \%$, respectively. Acetosyringone at $200 \mu M$ and co-cultivation at $28^{\circ} \mathrm{C}$ also gave the highest transformation efficiency (14.4 and $18.4 \%$, respectively). Meanwhile, inclusion of $20 \mathrm{~g} / \mathrm{L}$ maltose $+20 \mathrm{~g} / \mathrm{L}$ sorbitol into the regeneration media has significantly improve the transformed somatic embryos growth and increase the regeneration efficiency up to $40.0 \%$. The results of polymerase chain reaction (PCR) and reverse transcription-polymerase chain reaction (RT-PCR) indicated that the transgene was successfully integrated and overexpressed in transgenic rice of MR219. In conclusion, significant improvement in transformation efficiency for rice $c v$. MR219 has been obtained by using the optimised protocol for transformation and regeneration developed in this study.
\end{abstract}

Keywords: Maltose; regeneration; somatic embryo; sorbitol; transformation efficiency

ABSTRAK

Transformasi padi indica berperantarakan Agrobacterium merupakan proses yang mencabar disebabkan oleh sifat semula jadi padi yang rekalsitran terhadap transformasi. Oleh yang demikian, pengoptimuman protokol transformasi adalah amat penting untuk setiap kultivar padi indica yang khusus bagi memastikan keberkesanan transformasi. Dalam kajian ini, beberapa parameter penting yang menjejaskan kecekapan transformasi berperantarakan Agrobacterium telah dioptimumkan untuk mendapatkan padi transgenik daripada kultivar padi tempatan, MR219. Kalus embriogenik dipilih untuk diinokulasikan dengan Agrobacterium tumefaciens strain LBA4404 yang membawa plasmid pH2GW7-ABP57 dan mengandungi gen yang diminati, Auxin binding protein 57 (Abp57). Parameter transformasi yang dioptimumkan dalam kajian ini adalah masa rendaman, tempoh penanaman bersama, kepekatan asetosiringon, dan suhu penanaman bersama. Tempoh penanaman bersama selama empat hari dan perendaman kalus embriogenik dalam ampaian Agrobacterium selama 30 min adalah optimum untuk transformasi MR219 dengan masing-masing mempunyai kecekapan transformasi sebanyak $26.4 \%$ dan $16.0 \%$. Kepekatan asetosiringon dan suhu penanaman bersama yang optimum masing-masing adalah $200 \mu \mathrm{M}(14.4 \%)$ dan $28^{\circ} \mathrm{C}(18.4 \%)$. Selain itu, kajian turut mendapati bahawa penggunaan $20 \mathrm{~g} / \mathrm{L}$ maltosa +20 $\mathrm{g} / \mathrm{L}$ sobitol dalam media regenerasi telah meningkatkan transformasi pertumbuhan dan keupayaan regenerasi embrio somatik sehingga 40\%. Hasil tindak balas berantai polimerase (PCR) dan tindak balas berantai polimerase transkripsi berbalik (RT-PCR) menunjukkan bahawa transgen berjaya diintegrasikan dan diekspreskan dalam padi transgenik MR 19. Kesimpulannya, kecekapan transformasi untuk padi cv. MR219 telah ditingkatkan secara signifikan dengan menggunakan protokol transformasi dan regenerasi yang optimum daripada kajian ini.

Kata kunci: Embrio somatik; kecekapan transformasi; maltosa; regenerasi; sobitol

\section{INTRODUCTION}

Agrobacterium-mediated transformation has been extensively adopted in plant transformation due to its ability to generate low copy number of transgene and transfer relatively large fragment of DNA (Hiel \& Komari 2008; Oltmanns et al. 2010). Recently, this method has been widely used in transformation of various rice varieties, which was not in the host range of Agrobacterium 
(Karthikayen et al. 2011; Sahoo et al. 2011; Shri et al. 2012). This progress provides a new option for crop improvement to sustain growing demand of rice and also to study gene function in plant. Agrobacterium-mediated transformation is heavily relying on the establishment of tissue culture system, which is a paramount challenge for indica rice transformation. Optimal conditions are needed to induce the activation of Vir genes for transgene incorporation into the host plant genome. Besides, a high efficient regeneration system is also needed to regenerate the transformants. This step poses another constraint to the transformation of indica rice, which is recalcitrant to tissue culture (Ge et al. 2006; Li et al. 2013). There are several factors that play significant effects on the regeneration of transformants. Those factors include the starting explants, plant growth regulators, carbon sources, gelling agents and osmotic stress treatments.

In this study, we used indica rice cv. MR219 for Agrobacterium-mediated transformation. The MR219 is an elite rice cultivar that was developed by Malaysian Agricultural Research and Development Institute (Zainudin et al. 2012) and was widely adopted by paddy farmers in Malaysia (Alias 2002). Nevertheless, this cultivar is very sensitive to several environmental stress such as drought and salinity stress. With established transformation system, genetic engineering could offer an alternative way for the improvement of this particular cultivar by introducing useful genes.

The present study aims to produce transgenic rice overexpressing a stress related gene, Auxin Binding Protein 57 gene (Abp57) while at the same time develop a reliable transformation system for MR219. The Abp57 gene code for a soluble auxin-binding protein, which acts as a receptor to activate plasma membrane (PM) $\mathrm{H}^{+}$-ATPase (Lee et al. 2009) has many effects in plant growth and development. To establish this, several important transformation parameters were optimized, including infection time, acetosyringone concentration, co-cultivation period and co-cultivation temperature. Transformation efficiency is genotype specific and therefore optimization of the parameters is needed to ensure the transformation protocol is efficient and to help save cost. The effect of different carbon sources on shoot regeneration from somatic embryos that survived selection media was also studied. Optimization of the regeneration system is important because the low regeneration rate for transformed callus of MR219 pose a major hindrance in genetic improvement of this indica rice cultivar.

\section{MATERIALS AND METHODS}

\section{PLANT MATERIALS AND EXPLANTS PREPARATION}

Seeds of MR219 were harvested at dough stage from MARDI station (Seberang Prai). Dehusked seeds were surfacesterilized with $100 \%$ alcohol for 1-2 min and followed by gently shaking in 100\% Clorox supplemented with 1-2 drops of Tween-20 for $30 \mathrm{~min}$. Seeds were then rinsed five times with distilled water and dried on filter paper. Next, the seeds were cultured on callus induction media containing MS basal salt with B5 vitamin (Murashige \& Skoog 1962), $15 \mathrm{~g} / \mathrm{L}$ maltose, $1 \mathrm{mg} / \mathrm{L}$ 2,4-dichlorophenoxyacetic acid, 10 $\mathrm{mg} / \mathrm{L}$ 1-naphthaleneacetic acid and $0.4 \%$ gelrite at $\mathrm{pH} 5.7$ (Zuraida et al. 2010) and kept in the dark at $25 \pm 2{ }^{\circ} \mathrm{C}$ for 3 weeks. Embryogenic calli initiated from scutella were sub cultured on fresh callus induction media for three days before transformation.

\section{OVEREXPRESSION VECTOR AND AGROBACTERIUM CULTURE}

For rice transformation, Agrobacterium strain LBA4404 harbouring overexpression vector pH2GW7-ABP57 (NAAS, Republic of Korea) was used. The vector contains hygromycin phosphotransgerase ( $\mathrm{htlll}$ ) gene as selectable marker. Abp57 is driven by CaMV $35 \mathrm{~S}$ promoter. The Agrobacterium was grown for overnight in $5 \mathrm{~mL}$ liquid LB media supplemented with $50 \mathrm{mg} / \mathrm{L}$ rifampicin and 50 $\mathrm{mg} / \mathrm{L}$ spectinomycin in incubator shaker $(220 \mathrm{rpm})$ at $28^{\circ} \mathrm{C}$. Subsequently, aliquots of $1 \mathrm{~mL}$ bacterial suspension were transferred to $20 \mathrm{~mL}$ fresh liquid LB media supplemented with appropriate antibiotics and grown on incubator shaker $(220 \mathrm{rpm})$ at $28^{\circ} \mathrm{C}$. The cells were pelleted by centrifugation when $\mathrm{OD}_{600 \mathrm{~nm}}$ reached 0.6 and re-suspended in $20 \mathrm{~mL}$ infection media containing MS basal salt with B5 vitamin, $15 \mathrm{~g} / \mathrm{L}$ maltose, $10 \mathrm{~g} / \mathrm{L}$ glucose and $200 \mu \mathrm{M}$ acetosyringone at $\mathrm{pH}$ 5.6.

\section{PLANT TRANSFORMATION AND PARAMETERS OPTIMISATION}

Embryogenic calli were mashed with spatula to induce mild wounding and immersed in the bacterial suspension with slight agitation for $20 \mathrm{~min}$. The calli were blotted dry on sterile filter paper to remove excess Agrobacterium. The treated calli were then transferred to co-cultivation media supplemented with $200 \mu \mathrm{M}$ acetosyringone and incubated in dark at $28^{\circ} \mathrm{C}$ for three days. Subsequently, the calli were transferred to selection media supplemented with $30 \mathrm{mg} / \mathrm{L}$ hygromycin and $250 \mathrm{mg} / \mathrm{L}$ carbenicillin. Calli were subcultured on fresh selection media every two weeks for two months until the actively proliferating somatic embryos were observed.

Independent experiments were conducted to optimize four crucial parameters affecting the Agrobacteriummediated transformation efficiency in MR219 calli. Those parameters include the immersion time $(20,30,40,50$, 60 and $70 \mathrm{~min}$ ), co-cultivation period (1, 2, 3, 4 and 5 days), acetosyringone concentration $(0,100,200,300$ and $400 \mu \mathrm{M})$ and co-cultivation temperature $\left(22^{\circ} \mathrm{C}\right.$ low temperature and $28^{\circ} \mathrm{C}$ - high temperature). During optimization only, one parameter was changed and the rest were kept fixed. Transformation efficiency (\%) data was calculated based on the number of proliferating somatic embryos generated at the end of selection process. All experiments were carried out with three replicates per 
treatment and each replicate contains 25 infected calli. The experiments were repeated three times.

\section{REGENERATION OF TRANSFORMANTS}

Whitish somatic embryos obtained from selection process were cultured on pre-regeneration media containing $10 \mathrm{mg} / \mathrm{L}$ abscisic acid at $25^{\circ} \mathrm{C} \pm 2$. After 2 weeks, the somatic embryos were transferred to regeneration media containing various concentrations of maltose and sorbitol (Table 1) and incubated for six weeks. The growth of somatic embryos was observed every two weeks of culture. All experiments were carried out with three replicates per treatment and each replicate contains five somatic embryos. The experiments were repeated three times. Regeneration frequency was calculated from the percentage of regenerated somatic embryos.

Regenerated shoots were transferred to rooting media containing half strength MS basal salt with vitamin and 30 $\mathrm{g} / \mathrm{L}$ sucrose. After rooting, plantlets were transferred to sterilized vermiculite and grown for hardening process. Plantlets were then transferred to green house and grown into maturity. Transformation stages of MR219 with Abp57 were presented as in Figure 1.

\section{PCR SCREENING AND RT-PCR ANALYSIS}

The genomic DNA of transgenic plants were extracted from young leaves using Qiagen DNeasy plant mini kit. PCR analysis was carried out by using special primer set amplifying partial sequence of CaMV35S promoter and partial sequence of transgene Abp57. Primers used for transgene amplification were: 5'-CGCACAATCCCACTATCCTTCGCA-3' and 5'-CTTCTTGTTCCAGGATGCGTTGCC-3'. Reaction conditions were set up following the kit's protocol: denaturation at $95^{\circ} \mathrm{C}$ for $10 \mathrm{~min}$ followed by 35 amplification cycles $\left(94^{\circ} \mathrm{C} / 30 \mathrm{~s}, 60^{\circ} \mathrm{C} / 30 \mathrm{~s}, 72^{\circ} \mathrm{C} / 30 \mathrm{~s}\right)$ and final extension step at $72^{\circ} \mathrm{C}$ for $5 \mathrm{~min}$.

Total RNA was isolated from the leaves of transgenic plants using TRIzol ${ }^{\circledR}$ reagent (Life Technology, USA) according to the manufacturer's protocol. RNA obtained was then treated with Ambion ${ }^{\circledR}$ TURBO $^{\mathrm{TM}}$ DNAse to avoid genomic DNA contamination. RT-PCR was performed using the Maxima First Strand cDNA Synthesis Kit (Thermo Scientific, USA) according to the manufacturer standard. Primer set employed to amplify gene of interest (Abp57) and housekeeping gene (U6) were as follows: for Abp57 5'-ATGGCAGAGATTGTTAGTTC-3' and 5'-CTAAAATTTCAGGCGCAGTA-3'; for U6

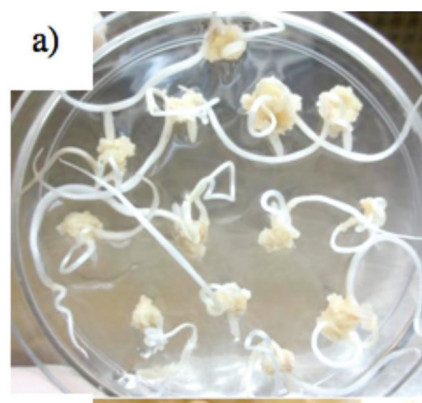

b)
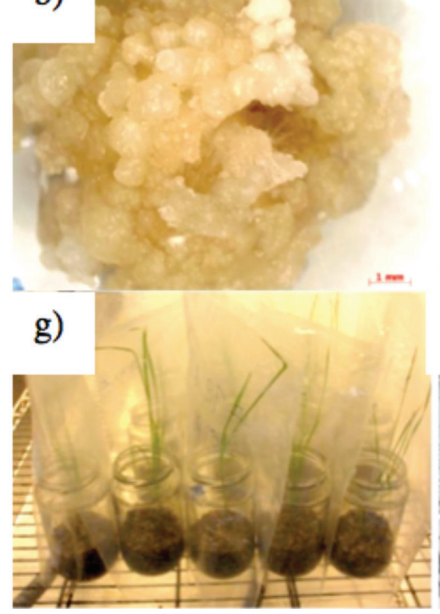

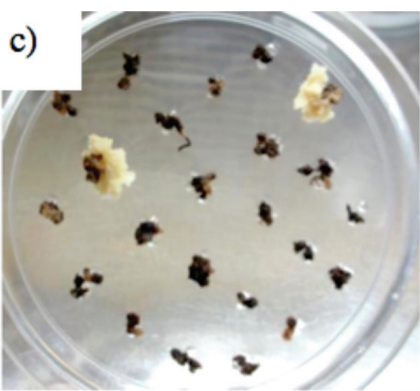

d)

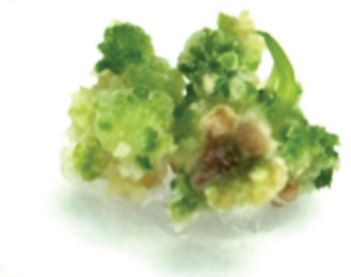

h)

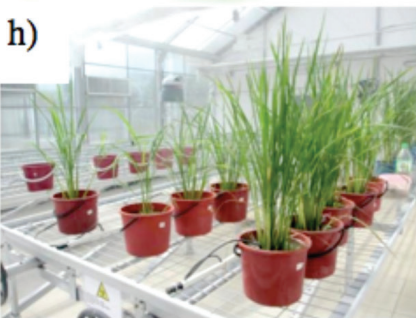

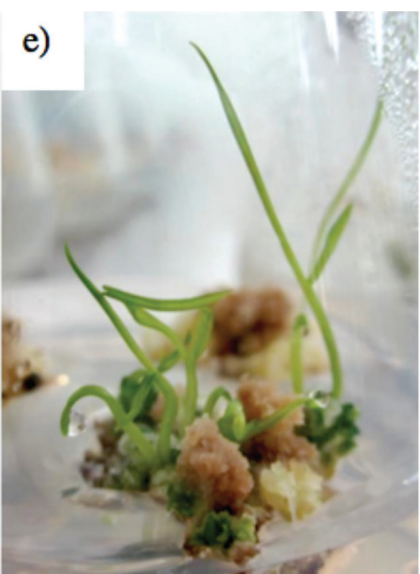

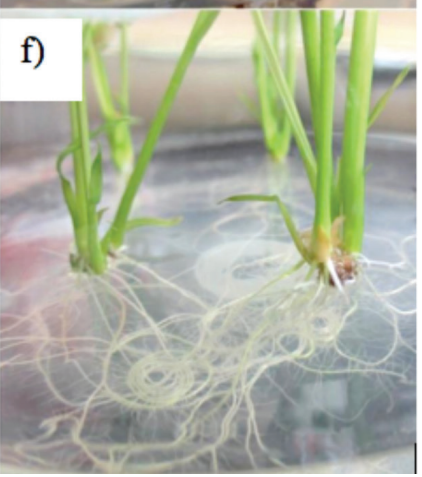

FIGURE 1. Different stages of agrobacterium-mediated genetic transformation of indica rice cv. MR219 with Abp57 gene. (a) callus induction on MSB5 media containing $1 \mathrm{mg} / \mathrm{L} \mathrm{2,4-D} \mathrm{and} 10 \mathrm{mg} / \mathrm{L}$ NAA (b) stereomicroscopic view of embryogenic callus used for transformation (c) actively proliferating somatic embryos formed after six weeks of selection (d) green somatic embryo with green shoot bud after four weeks incubation on regeneration media (e) multiple shoots formation after six week incubation on regeneration media (f) root formation of plantlets obtained from on rooting media containing $30 \mathrm{~g} / \mathrm{L}$ sucrose ( $\mathrm{g}$ ) acclimatization of complete plantlets in under controlled condition $(\mathrm{h})$ transgenic plants transferred to soil in transgenic glass house 
5' -TACAGATAAGATTAGCATGGCCCC-3' and 5'-GGACCATTTCTCGATTTGTACGTG-3'. All PCR amplification products were visualized by electrophoresis in $0.8 \%(\mathrm{w} / \mathrm{v})$ agarose-ethidium bromide gel.

\section{STATISTICAL ANALYSIS}

Data were analyzed with one-way ANOVA and differences between treatment means were tested using Duncan test at $5 \%$ level. The statistical analyses were performed using SAS 9.3 (SAS Institute Inc. USA).

\section{RESULTS}

\section{OPTIMIZATION OF RICE TRANSFORMATION CONDITIONS}

The indica MR219 transformation efficiency is affected by several factors such as immersion time, co-cultivation periods, acetosyringone concentration and temperature. These parameters were optimized and results were shown in percentage of actively proliferating somatic embryos grown on selection media. The transformation efficiency is dependent on the immersion time. Figure 2(a) shows that among the treatments, $30 \mathrm{~min}$ immersion time yielded the most efficient transformation $(26.4 \pm 1.0 \%)$ followed by 40 min immersion time $(22.4 \pm 1.0 \%)$. Longer immersion time did not give higher transformation efficiency. Immersion time of $20 \mathrm{~min}$ has the lowest transformation efficiency of $13.6 \pm 0.8 \%$. However, there is no significant difference between immersion time of 20,50,60 and $70 \mathrm{~min}$ for MR219 transformation with Abp57.

The highest transformation efficiency was observed between day three and day four of co-cultivation (Figure 2(b)) but there is significant difference between these two treatments. Day four $(16.0 \pm 1.3 \%)$ has higher percentage of proliferating somatic embryos formed at the end of selection compared to day three $(10.4 \pm 1.0 \%)$. One, two and five days of co-cultivation show no significant difference in transformation efficiency in MR219 transformation.

The effect of various acetosyringone concentrations in co-cultivation media was shown in Figure 2(c). The percentage of whitish embryos formation is significantly the highest in the presence of $200 \mu \mathrm{M}$ acetosyringone $(14.4 \pm 1.0 \%)$ compared with all other treatment. Nevertheless, concentrations of acetosyringone higher than $200 \mu \mathrm{M}$ significantly decrease the transformation efficiency of MR219. Inclusion of 300 and $400 \mu \mathrm{M}$ of acetosyringone have only $9.6 \pm 0.98 \%$ and $8.8 \pm 0.8 \%$ of transformation efficiency, respectively. Treatment without acetosyringone gave the lowest transformation efficiency, which is only $1.6 \pm 0.98 \%$.

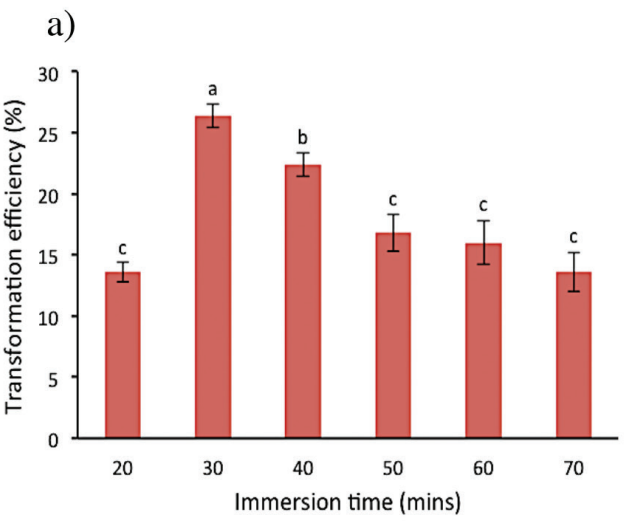

c)

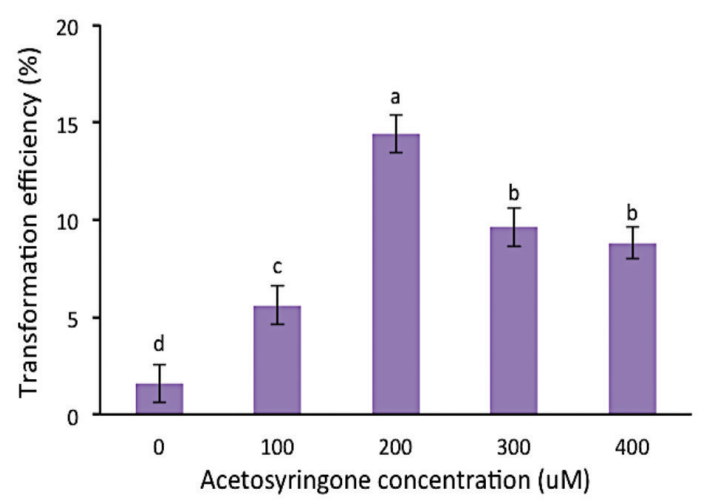

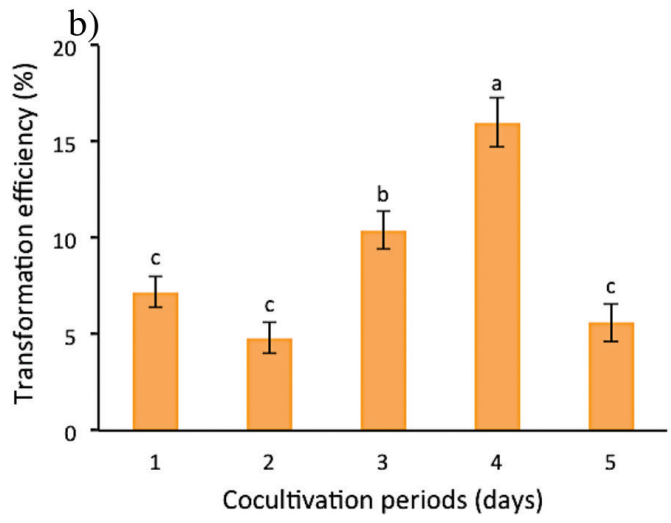

d)

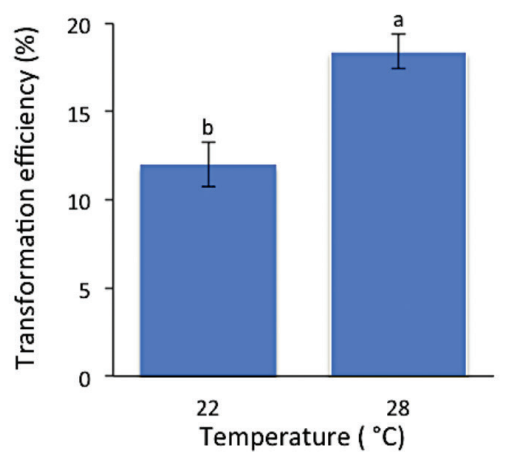

FIGURE 2. Effect of (a) immersion time, (b) co-cultivation periods, (c) acetosyringone concentration and (d) co-cultivation temperature on transformation efficiency of indica MR219 callus on selection media containing hygromycin. The columns and bars represent means and standard error (SE) of three replicates and experiments were repeated three times. Means with different letters are significantly different at $p \leq 0.05$ according to Duncan's multiple range test (DMRT) 
The influence of co-cultivation temperature on transformation efficiency of the MR219 with Abp57 was also investigated (Figure 2(d)). Co-cultivation at higher temperature $\left(28^{\circ} \mathrm{C}\right)$ has significantly higher transformation efficiency $(18.4 \pm 1.0 \%)$ compared to lower temperature $\left(22^{\circ} \mathrm{C}\right)$, which has only $12.0 \pm 1.3 \%$ of transformation efficiency.

\section{EFFECT OF MALTOSE AND SORBITOL ON IN VITRO PLANT REGENERATION}

Different concentrations of maltose and sorbitol individually or in combinations were added into regeneration media and the effects of each combination were investigated (Table 1). As expected, somatic embryos proliferate more actively and have minimal browning in higher maltose concentration at the second week of regeneration. During forth week of regeneration, treatments with only maltose shows no growth or slow growth in most part of the embryos. Inclusion of sorbitol into the regeneration media has greatly improved the somatic embryos growth at higher maltose concentration. The growth of somatic embryos can be maintained in regeneration media with higher concentration of maltose and sorbitol (treatment 15:15; 15:20 and 20:20 g/L). Table 1 indicates that somatic embryos growth is the most optimum in media with treatment $20 \mathrm{~g} / \mathrm{L}$ maltose $+20 \mathrm{~g} / \mathrm{L}$ sorbitol (20:20 g/L). Necrosis was observed within one week of regeneration and all treatments show necrosis of embryos after four weeks except treatment 20:20 $\mathrm{g} / \mathrm{L}$, which has very minimal browning. Data taken on the fourth week of regeneration (Figure 3) shows green spots formation is higher in treatments containing maltose and sorbitol combination compared to treatments that contained only maltose. The treatment with $20 \mathrm{~g} / \mathrm{L}$

TABLE 1. Effect of different concentrations of maltose and sorbitol on the growth of somatic embryos cultured on regeneration medium

\begin{tabular}{|c|c|c|c|c|c|c|}
\hline \multirow{2}{*}{\multicolumn{2}{|c|}{$\begin{array}{l}\text { Carbon source } \\
(\mathrm{g} / \mathrm{L})\end{array}$}} & \multicolumn{5}{|c|}{ Sorbitol } \\
\hline & & 0 & 5 & 10 & 15 & 20 \\
\hline \multirow{5}{*}{$\frac{\mathscr{d}}{\stackrel{0}{0}}$} & 0 & NG & $+/+$ & $++/+$ & $++/+$ & $+/+$ \\
\hline & 5 & $+/+$ & $+/+$ & $+/+$ & $++/+$ & $++/+$ \\
\hline & 10 & $++/+$ & $++/+$ & $++/++$ & $+++/++$ & $+++/++$ \\
\hline & 15 & $++/++$ & $++/++$ & $++/++$ & $+++/+++$ & $+++/+++$ \\
\hline & 20 & $+++/++$ & $+++/++$ & $+++/++$ & $+++/++$ & $++++/++++$ \\
\hline
\end{tabular}

* Growth of somatic embryos on the $2^{\text {nd }} / 4^{\text {th }}$ week, indicator: $\mathrm{NG}=$ no growth; $++++=$ active growth with minimal browning; $+++=$ moderate growth with browning; $++=$ slow growth and browning in most part of the somatic embryos; $+=$ growth almost retarded and browning severely

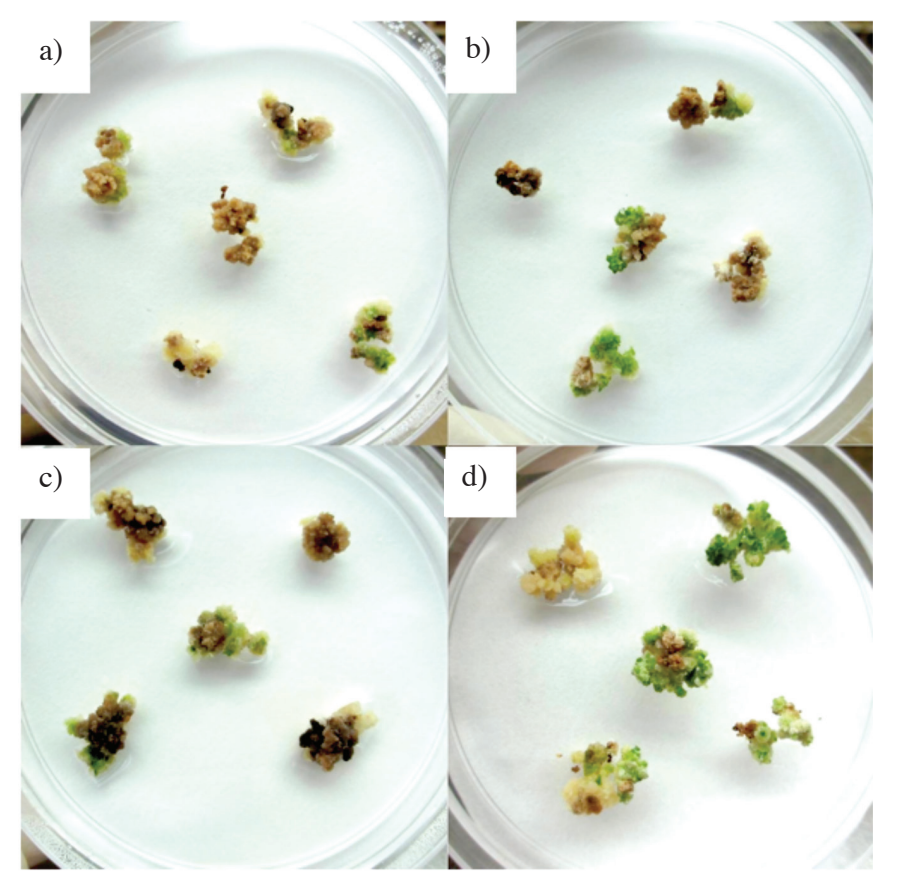

FIGURE 3. Green somatic embryos after four weeks on regeneration media containing (a) $15 \mathrm{~g} / \mathrm{L}$ maltose (b) $15 \mathrm{~g} / \mathrm{L}$ maltose and $15 \mathrm{~g} / \mathrm{L}$ sorbitol (c) $20 \mathrm{~g} / \mathrm{L}$ maltose (d) $20 \mathrm{~g} / \mathrm{L}$ maltose and $20 \mathrm{~g} / \mathrm{L}$ sorbitol 
maltose $+20 \mathrm{~g} / \mathrm{L}$ sorbitol (Figure 3(d)) has more green spots and less browning compared to $20 \mathrm{~g} / \mathrm{L}$ maltose (Figure 3(c)). Meanwhile, inclusion of sorbitol alone into the regeneration media does not help with the growth of somatic embryos.

Among the various treatments tested, regeneration media with $20 \mathrm{~g} / \mathrm{L}$ maltose $+20 \mathrm{~g} / \mathrm{L}$ sorbitol $(20: 20 \mathrm{~g} / \mathrm{L})$ gave the highest shoot regeneration frequency (40\%) but was not significantly different from the treatment of $15: 15 \mathrm{~g} / \mathrm{L}(33.3 \pm 6.7 \%)$ and $15: 20 \mathrm{~g} / \mathrm{L}(33.3 \pm 6.7 \%)$. On the other hand, the regeneration frequency is the same in treatments with only maltose and $5 \mathrm{~g} / \mathrm{L}$ sorbitol combination. Treatments with only maltose or $5 \mathrm{~g} / \mathrm{L}$ sorbitol combinations have lower regeneration frequency as compared to treatments with maltose and 15-20 g/L sorbitol combinations. However, there is no shoot formed in regeneration media that contain only sorbitol, treatment 5:0 $\mathrm{g} / \mathrm{L}$ and treatment 5:5 $\mathrm{g} / \mathrm{L}$.

\section{PCR SCREENING AND RT-PCR ANALYSIS}

PCR screening was carried out to confirm the presence of transgenes. Figure 4 shows the results of amplified PCR product $(467 \mathrm{bp})$ from independent lines of putative transformants. The expected fragment of partial CaMV35S promoter and transgene was present. Sequencing results have also confirmed the bands are the desired sequence. The RT-PCR analysis also shows that the transgene is overexpressed in five independent lines of transgenic plants (Figure 5). Nevertheless, the endogenous Abp57 was also detected in wildtype plant but at a very low level as compared to transgenic rice plants overexpressing Abp57 gene.

\section{DISCUSSION}

\section{TRANSFORMATION OPTIMIZATION}

Monocotyledons including indica rice were difficult to transform because it is lack of wound response- induction of cell division at wound site (Hiel et al. 2014). However, the transformation of rice was made easier recently by optimizing a few important factors such as tissue culture conditions, uses of Vir genes inducer and choices of explants used for transformation. In Agrobacteriummediated transformation of MR219, embryogenic callus was infected with Agrobacterium by immersion in bacterial culture. The periods of immersion has shown significant effects on the transformation efficiency. This step allows sufficient Agrobacterium to attach to the explants. From previous studies, immersion periods for

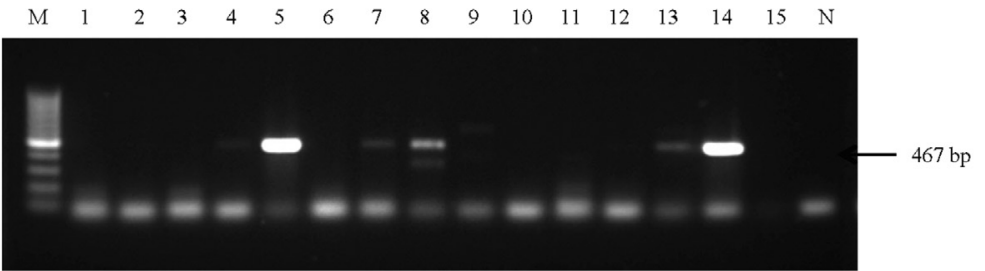

FIGURE 4. Polymerase chain reaction (PCR) analysis of genomic DNA extracted from putatively transformed plants using transgene specific primer set. Lane M, marker; lane 1 and 2, wildtype; lanes 3-15, putative transgenic plants; lane $\mathrm{N}$, no template control

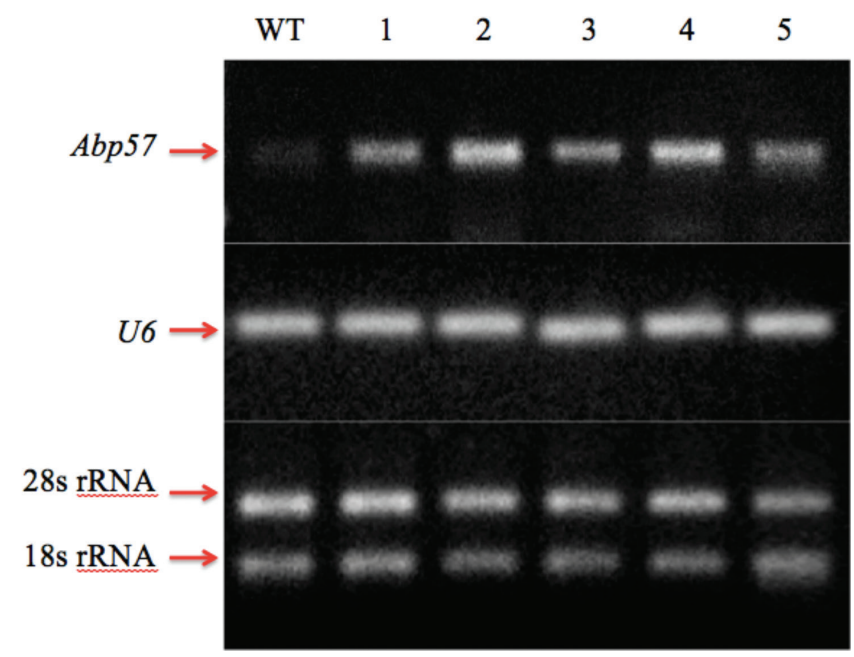

FIGURE 5. RT-PCR analysis of transgenic rice at T1 generation. Lane M, marker; lanes W, wild type; lane 1-5, independent transgenic lines overexpressing Abp57 gene. U6 housekeeping gene was used as endogenous control 
rice transformation could be range from 2 to $30 \mathrm{~min}$ (Hiel \& Komari 2008; Sahoo et al. 2011). Our result showed that $30 \mathrm{~min}$ of immersion is optimum for the highest transformation efficiency $(26.4 \pm 1.0 \%)$ in MR219. Extended Agrobacterium inoculation time could cause explants necrosis due to plant defense responses to the pathogen (Zhang et al. 2013). Moreover, optimum immersion time is also important because extended immersion time could also cause Agrobacterium over growth during selection stage. This could make the culture works more tedious and troublesome during sub-culturing process.

Besides, the duration of co-cultivation has significant effect on transformation efficiency. The standard cocultivation period for rice was two to three days (Wang 2015). In our study, four days of co-cultivation was identified as the optimum for transformation of MR219 with transformation efficiency $16.0 \pm 1.3 \%$. Recent studies show that the optimum period of co-cultivation for indica rice cv. IR64 was five days (Shri et al. 2012). The cocultivation period must be long enough to ensure transgene transfer from Agrobacterium to host plant. Further increase in co-cultivation period tends to cause Agrobacterium over growth or callus necrosis, resulting in the decrease of transformation efficiency (Gnasekaran et al. 2014; Nanasato et al. 2013).

The optimized transformation protocol will enable transformation of rice to be carried out at a higher successful rate. One of the important factors contributing to successful of rice transformation is the usage of acetosyringone during co-cultivation. Acetosyringone mimic phenolic inducer produced naturally by plants at the wounded site to attract Agrobacterium by chemotaxis (Pérez et al. 1999) and induces Vir gene expression in the bacteria to transfer T-DNA fragment or transgene into host plant (Tzfira et al. 2006). Many studies reported that the use of phenolic inducer such as acetosyringone was essential during gene transfer in most plants species, especially the recalcitrant monocots (Ozawa 2009). However, the use of optimum concentration of acetosyringone is important to avoid low transformation efficiency or necrosis of explants (Karthikeyan et al. 2011).

\section{REGENERATION OF TRANSFORMED SOMATIC EMBRYO}

It is noted that explant regeneration is one of the major challenge in many indica rice genetic transformation studies. This problem might be due to the unsuitable media used during the explant regeneration and effect from harsh transformation procedure. Most of the experiments on regeneration were conducted using wildtype instead of explants that have undergone transformation procedure. In this case, Arash et al. (2010) have suggested that the requirement for regeneration of putative transformants and wildtype plant is different due to the exposure to Agrobacterium and stress during selection. Therefore, we test the effect of sorbitol on the regeneration of transformed somatic embryos. Our results showed that the addition of $20 \mathrm{~g} / \mathrm{L}$ sorbitol to regeneration media has greatly improves the regeneration abilities of the transformants to as high as $40.0 \%$. Moreover, it also reduces the callus necrosis, enhances callus growth and increases regeneration frequency of the transformants.

Recently, cDNA-AFLP results by Feng (2011) suggested that sorbitol acts as carbon source, osmotic regulator and chemical signal to alter gene expression for enhancing plantlet regeneration frequency of rice callus. On the other hand, Lee et al. (2014) hypothesized that osmotic stress by sorbitol may regulate endogenous levels of auxin interacting with ABA to promote shoot organogenesis. In our study, there was no shoot regenerated from media containing only sorbitol (Table 2). This result is in accordance with report by Cho et al. (2004) where sorbitol alone will delay the rice callus growth. This may suggest that sorbitol role, as an osmotic regulator is more prominent than as a primary carbohydrate in callus regeneration of MR219. It must be used together with maltose to enhance regeneration efficiency of MR219.

\section{CONCLUSION}

Agrobacterium-mediated transformation technique was successfully applied on indica rice cv. MR219 by using an overexpression vector carrying Abp57. A few important transformation parameters and carbon sources used in regeneration media have been optimized. The addition of

TABLE 2. Percentage of somatic embryos that was able to regenerate on media containing differrent concentrations of maltose and sorbitol

\begin{tabular}{|c|c|c|c|c|c|c|}
\hline \multirow{2}{*}{\multicolumn{2}{|c|}{$\begin{array}{l}\text { Carbon source } \\
(\mathrm{g} / \mathrm{L})\end{array}$}} & \multicolumn{5}{|c|}{ Sorbitol } \\
\hline & & 0 & 5 & 10 & 15 & 20 \\
\hline \multirow{5}{*}{ 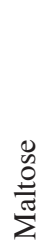 } & 0 & 0 & 0 & 0 & 0 & 0 \\
\hline & 5 & 0 & 0 & $6.7 \pm 6.7^{\mathrm{de}}$ & $13.3 \pm 6.7^{\mathrm{d}}$ & $20.0^{\mathrm{cd}}$ \\
\hline & 10 & $6.7 \pm 6.7^{\text {de }}$ & $6.7 \pm 6.7^{\text {de }}$ & $13.3 \pm 6.7^{\mathrm{d}}$ & $20.0^{\mathrm{cd}}$ & $20.0^{\mathrm{cd}}$ \\
\hline & 15 & $20.0^{\mathrm{cd}}$ & $20.0^{\mathrm{cd}}$ & $20.0^{\mathrm{cd}}$ & $33.3 \pm 6.7^{\mathrm{ab}}$ & $26.7 \pm 6.7^{b c}$ \\
\hline & 20 & $20.0^{\mathrm{cd}}$ & $20.0^{\mathrm{cd}}$ & $26.7 \pm 6.67^{\mathrm{bc}}$ & $33.3 \pm 6.7^{\mathrm{ab}}$ & $40.0^{\mathrm{a}}$ \\
\hline
\end{tabular}

*Data represent mean \pm standard error of three replicates and experiment was repeated three times. Different letters indicate values are significantly different $(p \leq 0.05)$ 
sorbitol could increase the shoots regeneration frequency of MR219. With these findings, genetic transformation of MR219 with useful important genes would be applicable in the future.

\section{ACKNOWLEDGEMENTS}

This work is funded by of Ministry of Higher Education, Malaysia (LRGS/TD/2011/UPM-UKM/KM/03) and Improving Rice Grant (PJ008574) by Rural Development Administration (RDA), Suwon, Republic of Korea awarded to Dr. Zamri Zainal. Tan L.W. is a recipient of the MyBrain $15, \mathrm{KPT}$.

\section{REFERENCES}

Alias, I. 2002. MR 219, a new high-yielding rice variety with yields of more than $10 \mathrm{mt} / \mathrm{ha}$. MARDI, Malaysia. FFTC: Research Highlights RH2002-10.

Arash, R., Maheran, A.B., Azmi, A.R., Siti, N.A.A., Hossein, K., Sirchi, M.H.T. \& Javadi, M.B. 2010. Optimization of Agrobacterium tumefaciens-mediated transformation and shoot regeneration after co-cultivation of cabbage (Brassica oleracea subsp. capitata) cv. KY Cross with AtHSP101 gene. Scientia Horticulturae 124: 1-8.

Cho, J.H., Lee, J.Y. \& Kim, Y.W. 2004. Improvement of shoot regeneration from scutella-derived callus in rice. Korean Journal of Crop Science 49: 52-60.

Feng, X., Zhao, P., Hao, J., Hu, J., Kang, D. \& Wang, H. 2011. Effects of sorbitol on expression of genes involved in regeneration of upland rice (Oryza sativa L.). Plant Cell, Tissue and Organ Culture 106: 455-463.

Gnasekaran, P., Jessica, J.J.A., Jasim, U. \& Sreeramanan, S. 2014. Agrobacterium-mediated transformation of the recalcitrant Vanda Kasem's Delight orchid with higher efficiency. The Scientific World Journal 2014: Article ID. 583934.

Ge, X., Chu, Z., Lin, Y.\& Wang, S. 2006. A tissue culture system for different germplasms of indica rice. Plant Cell Reports 25: 392-402.

Hiel, Y., Ishida, Y. \& Komari, T. 2014. Progress of cereal transformation technology mediated by Agrobacterium tumefaciens. Frontiers in Plant Science 5: 1-11.

Hiel, Y. \& Komari, T. 2008. Agrobacterium-mediated transformation of rice using immature embryos or calli induced from mature seed. Nature Protocol 3: 824-834.

Karthikeyan, A., Pandian, S.K. \& Ramesh, M. 2011. Agrobacterium-mediated transformation of leaf base derived callus tissues of popular indica rice (Oryza sativa L. subsp. indica cv. ADT 43). Plant Science 181: 258-268.

Lee, K., Kim, M.I., Kwon, Y.J., Kim, M., Kim, Y.S. \& Kim, D. 2009. Cloning and characterization of a gene encoding ABP 57, a soluble auxin-binding protein. Plant Biotechnology Reports 3: 293-299.

Lee, S.T. \& Huang, W.L. 2014. Osmotic stress stimulates shoot organogenesis in callus of rice (Oryza sativa L.) via auxin signaling and carbohydrate metabolism regulation. Plant Growth Regulation 73: 193-204.

Li, H., Yang, Y., Duan, Y., Li, J., Cong, X., Ni, D., Song, F., Li, L., Wei, P. \& Yang, J. 2013. Mapping QTLs for the tissue culture performance of rice mature embryo using indicajaponica recombinant inbred lines. Australian Journal of Crop Science 7: 440-445.
Murashige, T. \& Skoog, F. 1962. A revised medium for rapid growth and bioassay with tobacco tissue culture. Physiologia Plantarum 15: 473-479.

Nanasato, Y., Konagaya, K., Okuzaki, A., Tsuda, M. \& Tabei, T. 2013. Improvement of Agrobacterium-mediated transformation of cucumber (Cucumis sativus L.) by combination of vacuum infiltration and co-cultivation on filter paper wicks. Plant Biotechnology Reports 7: 267-276.

Oltmanns, H., Frame, B., Lan-Ying, L., Johnson, S., Bo, L., Kan, W. \& Gelvin, S.T. 2010. Generation of backbone-free, low transgene copy plants by launching T-DNA from the Agrobacterium chromosome. Plant Physiology 152: 11581166.

Ozawa, K. 2009. Establishment of a high efficiency Agrobacteriummediated transformation system of rice (Oryza sativa L.). Plant Science 176: 522-527.

Pérez Hernández, J.B., Remy, S., Galán Saúco, V., Swennen, R. \& Sági, L. 1999. Chemotactic movement and attachment of Agrobacterium tumefaciens to banana cells and tissues. Journal of Plant Physiology 155: 245-250.

Sahoo, K.K., Tripathi, A.K., Pareek, A., Sopory, S.K. \& Pareek, S.L.S. 2011. An improved protocol for efficient transformation and regeneration of diverse indica rice cultivars. Plant Methods 7: 49.

Shri, M., Rai, A., Verma, P.K., Misra, P., Dubey, S., Kumar, S., Verma, S., Gautam, N., Tripathi, R.D., Trivedi, P.K. \& Chakrabarty, D. 2012. An improved Agrobacterium-mediated transformation of recalcitrant indica rice (Oryza sativa L.) cultivars. Protoplasma 250: 631-636.

Tzfira, T. \& Citovsky, V. 2006. Agrobacterium-mediated genetic transformation of plants: Biology and biotechnology. Current Opinion in Biotechnology 17: 147-154.

Wang, K. 2015.Agrobacterium Protocols. vol. 1,3rd ed.Methods in Molecular Biology 1223: 17-349.

Zainudin, P.M.D., Hussain Amirrudin, M., Badrulhadza, A., Marzuki, H. \& Mohd. Bahagia A.G. 2012. Buletin Teknologi MARDI Bil.1: 01-10.

Zhang, W.J., Dewey, R.E., Boss, W., Phillippy, B.Q. \& Qu, R. 2013. Enhanced Agrobacterium-mediated transformation efficiencies in monocot cells is associated with attenuated defense responses. Plant Molecular Biology 81: 273-286.

Zuraida, A.R., Suri, R., Wan Zaliha, W.S. \& Sreeramanan, S. 2010. Regeneration of Malaysian indica rice (Oryza sativa L.) variety MR 232 via optimised somatic embryogenesis system. Journal of Phytology 2: 30-38.

Lay-Wen Tan, Hoe-Han Goh, Ismanizan Ismail \& Zamri Zainal* Institute of Systems Biology (INBIOSIS)

Universiti Kebangsaan Malayasia

43600 UKM Bangi, Selangor Darul Ehsan

Malaysia

Zuraida A. Rahman

Biotechnology Research Centre, MARDI Headquarters

Persiaran MARDI-UPM

43400 Serdang, Selangor Darul Ehsan

Malaysia

Duk-Ju Hwang

National Academy of Agricultural Science

RDA, Suwon 441-857

Korea 
Ismanizan Ismail \& Zamri Zainal*

School of Biosciences and Biotechnology

Faculty of Science and Technology

Universiti Kebangsaan Malayasia

43600 UKM Bangi, Selangor Darul Ehsan

Malaysia
*Corresponding author; email: zz@ukm.my

Received: 18 January 2016

Accepted: 24 October 2016 